\title{
German nursing shortage in hospitals - Homemade by Profititis?
}

\author{
Björn L.D.M. Brücher ${ }^{1,2,3, *}$, and Daniela Deufert ${ }^{4}$ \\ ${ }^{1}$ Theodor-Billroth-Academy ${ }^{\circledR}$, Munich, Germany - Sacramento, CA, USA \\ ${ }^{2}$ INCORE, International Consortium of Research Excellence of the Theodor-Billroth-Academy ${ }^{\circledR}$, \\ Munich, Germany - Sacramento, CA, USA \\ ${ }^{3}$ Department of Surgery, Carl-Thiem-Klinikum, Cottbus, Germany \\ ${ }^{4}$ Department of Nursing Science and Gerontology, UMIT - Private University for Health Sciences, \\ Medical Informatics and Technology, Hall in Tyrol, Austria
}

Received 17 December 2018, Accepted 19 March 2019

\begin{abstract}
The shortage of nursing staff in Germany compromises public healthcare in deference to profits explaining why this is on the daily political and media agenda. In Germany, over a 22 year period, significant savings were achieved by decreases in: (1) hospital beds by $-29.3 \%$ saving 119000 beds, (2) patient care and treatment days by $-23 \%$ saving 43.1 million patient days, and (3) length of hospital stay in days by $-39 \%$ saving 4.7 days. This occurred together with the parallel increase of treated patient cases by $+26.5 \%$ with an additional burden of 4.1 million patients. Since 2010, as birth rates increase again treatment cases will also increase. In parallel, the percentage of total nurses has decreased $(-2.1 \%)$ as well as that of registered nurses in hospitals between 1999 (325 539) and 2009 (324 337) have decreased (-0.4\%), in conjunction with nurses employed in preventive and rehabilitation facilities $(+15.1 \%)$ and/or in outpatient care facilities $(+41.1 \%)$ and/or nursing homes $(+24.8 \%)$ and/or nurses working in retirement homes $(+77.9 \%)$. This "profititis" endangers both patient care and detracts from people joining the nursing profession. It might even be a short-sighted tightrope act which, in the end, might counteract the marketing strategy of "patient safety" by risking quality of patient care. Maybe healthcare politics would be well-advised to re-think the fact that as the population gets older and as birth rates and immigration increases, these factors could result in increased patient caseloads in hospitals which need to be addressed now so as to avert a future crisis.
\end{abstract}

Keywords: Administration, Base rate, BW, Basisfallwert, BWR, Benchmarking, Bureaucratization, Business enterprises, Control-based management, CBM, Cost weight, CW, DKG, Diagnosis-related group, DRG, Economics, Economy, Epidemiology, Employee, Ethics, Elective care, Germany, GKV, Health, Healthcare, Hospital, Hospital administration, HA, Human resource management, HRM, Leadership, Master of business administration, MBA, Money, Nurse, Nursing, Patient safety, Operationen- und Prozedurenschlüssel, Ops-code, Physician, Quality, PKV, PPR, PpUVG, Profit, Profititis, Quality management, QM, Registered nurse, Science, Standardized operative procedures, SOP, Surgery, University

\section{Introduction}

The current average population increase is estimated at 82 million people per year and indicates that the world population will reach 10 billion by 2055 and 11 billion in the year 2088 [1]. Furthermore, there is an increase of ageing as the proportion of people above 60 years old will increase from 841 million at present to an estimated 2 billion by 2050 according to the World Health Organization (WHO) [2]. The logical consequence is an increase of the burden of age-related chronic diseases together with healthcare costs worldwide. The healthcare economics already overwhelms economic variables such as benchmarking which

*Corresponding author: b-bruecher@gmx.de is sold as being helpful to increase quality, though in reality it is too often abused for staffing reductions to save money so as to more effectively compete in the market of competitive healthcare. It may be argued that the benchmarking in healthcare already is more related to the prestige of the hospital rather than a criterion of excellence. The reasons for the "businessization", a term coined by Michele Pagano in 2017 [3, 4], of healthcare are complex, but one observable condition in both science and healthcare, is the increased misuse of mathematical variables, such as benchmarking.

Consistent cutbacks of nursing staff include a high risk of the appeal for future generations in making the decision to enter into nursing given the stigma to the profession. In this regard, independent from its subject and specialty, 
nursing is inseparable from physicians, medicine, science, and education and we should be aware that:

A physician is nothing without a nurse and vice versa. The reputation and value of each single university, hospital, administration, physician, and nurse is inseparable from individuals and its employers. This even influences the reputation and quality of a city, state and country.

This article considers the German nursing shortage in registered nurses in German healthcare politics including financing, diagnosis-related groups (DRG), cost weight $(\mathrm{CW})$ and base rate (BR), nursing staff regulation (German: Pflegepersonalregelung, PPR), basics in hospital leadership, economy - Benchmarking, nurse staffing and patient risk, nursing in Germany and nursing staffing in other countries. This is completed by the new German personnel lower limit regulation (German: Pflegepersonaluntergrenzen-Verordnung, $P p U V G)$. The content dealing with politics, management, and economics shows how ethical considerations may help serve as a more objective basis for possible solutions. The focus of this paper is how staff shortage in nursing occurred and what its implications might be.

\section{Basics in German health care politics German health care politics}

German Federal States with population, capital and number of hospitals together with beds per 100000 citizen, case patients per 100000 citizen, numbers of full-time nurses with average numbers of beds per day per nurse from the German Federal Office of Statistics are given in Table 1 [5]. The data provide a mix of variables in accordance with the geographic, political and economic heterogeneity of each Federal State.

Health is declared as being the highest good. By German law, protected legal interest are, in particular, life, the body, health, freedom and property according to $\$ 823$ Abs. 1 BGB. Therefore, hospitals serve public health, the individual and common good and are of public interest and the top task of hospitals should be the optimal treatment of patients. According to 2017 German Hospital Society DKG (German: Deutsche Krankenhausgesellschaft, $D K G$ ) data, 1951 hospitals with 498718 beds, 19532779 patient cases, 158148 physicians and 722371 non-physician employees with just 325119 nurses in Germany [6].

\section{Financing of hospitals in Germany}

In Germany, financing of hospitals is the responsibility of carriers and owners. On the one hand, hospitals have to operate economically but hospitals are not commercial enterprises. Nowadays, case rates of health insurances finance the operating costs of hospitals including that of the university hospitals in Germany. Investment costs are financed by the States resulting in a "dual system". University hospitals incorporate a special task as engines of science and clinical research. Furthermore, Universityfree (often University-associated) research institutions are also available, e.g. such as the Max-Planck Society, the Fraunhofer Society, the Helmholtz Association, and the Leibnitz Association. Their financing differs from state to state and is independent from the State budgets as well as from private funds. This is one significant (undervalued both in Germany and abroad) difference from private US university hospitals: a complete different (better: missing) culture of philanthropy.

\section{Diagnosis-related groups (DRG) system}

Until 2002, the financing of German healthcare was done by a mixed calculation of same-day nursing care rates (80\%) and through lump-sum payments or special charges $(20 \%)$. The diagnosis-related groups (DRG) system was established in a step-wise fashion in Germany to try to control the financing of German healthcare starting in 2003 in an optional manner initially and mandated from 2004. The legal basis is $\S 85 \mathrm{SGB} V$ and $\S 17 \mathrm{~b}$ of the Hospital Financing Act (German: Krankenhausfinanzierungsgesetz, $K H G)$.

The DRG system was originally initiated by the surgeon, Eugene Codman [7] at the Massachusetts General Hospital, Robert Barclay Fetter and John Devereaux Thompson at Yale University who tried to develop a usable program for quality assurance in hospitals in $1967([8,9]$ reviewed in [10]). It was the intent to work against a healthcare cost explosion. They focused on comparable variables such as surgical procedures, postoperative complications, patient age, as well as total charges, length of patient stay, and case mix. The physician, Dr. Joanne Finley, pushed forward, and in 1980, twenty-six hospitals in New Jersey volunteered and adopted the system ([11] reviewed in [10]). In 1983, the DRG system was adopted by Medicare in the USA.

The Australian Refined Diagnosis Related Groups (AR-DRG) was the basis to overhaul the DRG system in Germany. An independent institute was founded in 2001 by the central associations of German health insurance companies (German: Spitzenverbände der Krankenkassen, $G K V)$, the federation of private health insurance companies (German: Verband der privaten Krankenversicherungen, $P K V$ ) and the German Hospital Company (German: Deutsche Krankenhausgesellschaft, DKG) for the introduction and continuous development of the German DRG system according to $§ 17 \mathrm{~b}$ KHG: the Institute for Remuneration System in Hospitals (German: Institut für das Entgeltsystem im Krankenhaus in Siegburg, InEK gGmbH) although it was known early that the implementation of the AR-DRG would not result in a decrease of the healthcare expenditures $[12,13]$. In 2009, this was already called "the industrialization of German healthcare" as no scientific proof could be provided that the introduction and use of the DRG system resulted in a financial benefit or administrative expenses [13]. This meant that the primary intent to create/overtake a healthcare financial system to handle healthcare expenses more efficiently and which would not lose money had failed. However, despite dozens of variables in use, some of which are explained here to give an overview 
Table 1. German Federal States with population, capital, and number of hospitals.

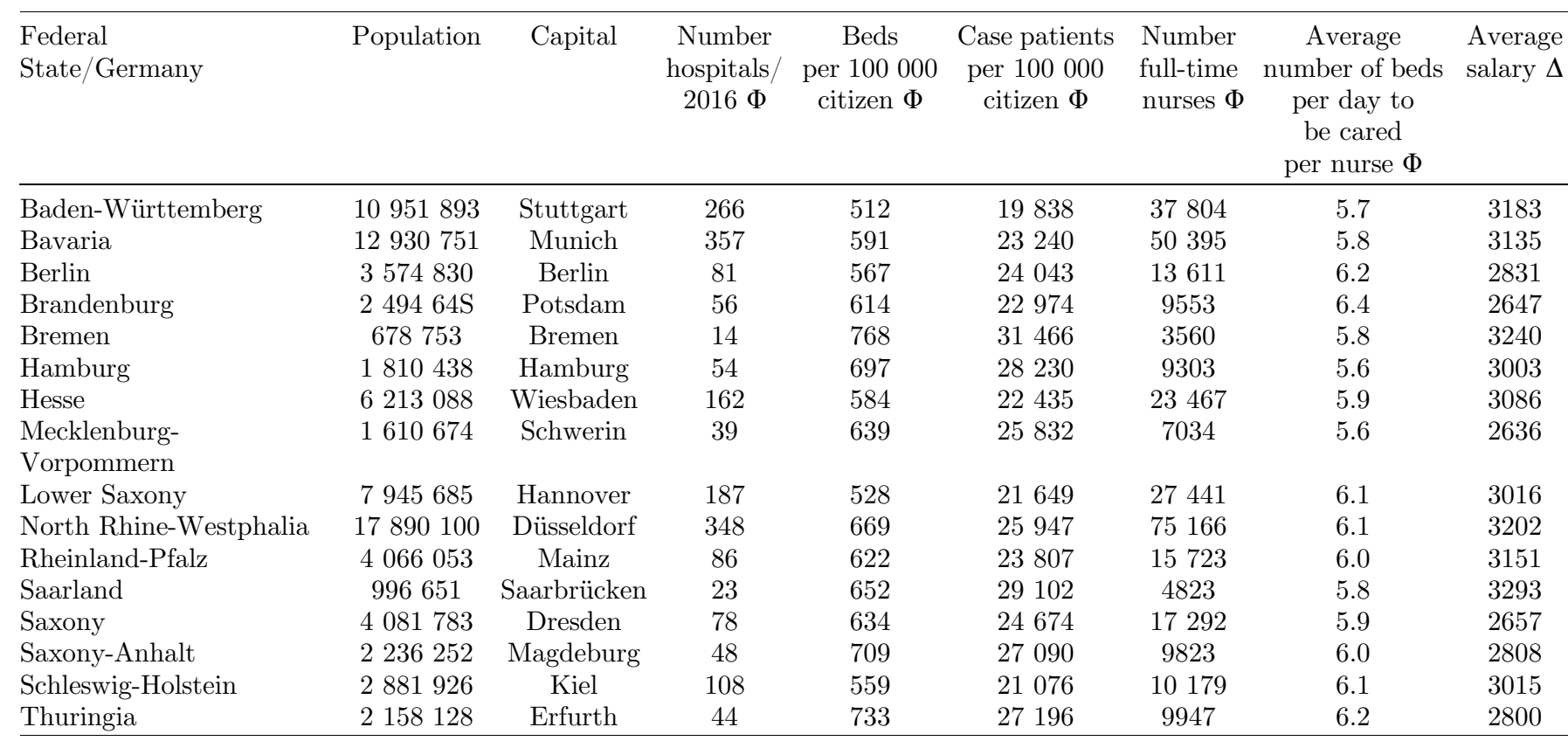

German Federal States with population, capital, and number of hospitals, together beds per 100000 citizen, case patients per 100000 citizen, number of full-time nurses and average number of beds per day to be cared per nurse: $\Phi=$ data in accordance to [5]. Average nurse salary in accordance to an analysis from 2013 data by the Institute for Employment Research (Institut für Arbeitsmarkt- und Berufsforschung, IAB): $\Delta$ = data (median gross salary payment) in accordance to [100].

of how the German DRG system works which is necessary to understand conclusions drawn $[14,15]$.

\section{Cost weight $(\mathrm{CW})$, base rate $(\mathrm{BR})$}

In German health economics, one important variable is the cost weight (CW) (German: Bewertungsrelation, $B W R)$. This relative variable is determined for the respective valid DRG catalogs. The basis for this calculation is by law $\S 301$ SGB V, and for its calculation the ICD-code, secondary diagnosis (comorbidities), the kind of therapy by the operation and procedure key (German: Operationenund Prozedurenschlüssel, OPS-code) as well as age, sex, duration of ventilation and cost data from hospitals which participate in a nationwide calculation. This generates a theoretical average case patient with a weighting ratio of 1.0, and more expensive cases compared to the average get a higher weighting $(>1.0)$ with less expensive cases $<$ 1.0. Multiplication of the $\mathrm{CW}$ with the base rate $(\mathrm{BR})$ (German: Basisfallwert) is the amount used to calculate hospital-related diagnosis-related groups (DRG) prices. The result is the amount the health insurance company has to pay to a hospital for such an individual treatment case. Example: a CW of 0.96 with a BR of $€ 2900$ results in $€ 2784$ - which the health insurance company will pay to the hospital.

The development of BR occurred between 2003 and 2004 on an individual basis for each hospital while a performance planning (German: Leistungsplanung) was agreed to by the preparation of planned DRGs. In this way, the BR is calculated out of the total budget divided by the sum of the CWs. This was done in Germany between 2005 and 2009 for each federal state resulting in federal state CWs (German: Landesbasisfallwert). These federal CWs were aligned in five equal convergence steps to receive a German federal CW (German: Bundesbasisfallwert).

The central associations of health insurance companies (German: Spitzenverbände der Krankenkassen, GKV), the federation of private health insurance (German: Verband der privaten Krankenversicherungen, $P K V)$ and the German hospital company (German: Deutsche Krankenhausgesellschaft, DKG) in 2001 founded an institute for the calculation for the remuneration system of hospitals as a legal non-profit company with limited liability German: Institut für das Entgeltsystem im Krankenhaus in Siegburg, InEK GmbH). This was changed in 2007 to the legal form of a company with limited liability. Shareholders are the DKG, the PKV and GKV. Other important variables used in hospitals are mentioned in the section titled, "benchmarking".

\section{Nursing staff regulation (German: Pflegepersonalregelung, PPR)}

Nursing is considered within the DRG system by staff regulations for patients in hospitals at the ward (German: Pflegepersonalregelung, PPR). PPR values per minute were calculated for the rule of $14 \mathrm{~h}$ between 6 am and $8 \mathrm{pm}$ while the staffing calculations for night shifts were based on the working place method. This was established as a part of 
the German Healthcare Act (German: Gesundheitsstrukturgesetz) as of December 21, 1992 and contained formula for personnel allocation in staffing for nurses [16]. The main criticism of PPR was: the real personnel nurse staffing did not consider the needs of patients nor the real nursing care expenses for any given patient type, and only a reference variable $P P R$-minutes was used to distribute actual personnel costs. It should be mentioned that there was never a scientific evaluation of the PPR in regard to validity and/or reproducibility. In accordance with the PPR, nursing care categories were created in regards to adults, children with age intervals and nursing care levels differentiated in general nursing care (German: Allgemeine Pflege) and special care (German: Spezielle Pflege). First in 1996, the PPR was suspended as it triggered additional costs, followed by its abrogation. In 2006, the PPR was used for calculation purposes.

Although the PPR in general makes little sense since the introduction of the DRG system, an obscure situation occurred which is still used as a control instrument in hospitals for internal "benchmarking" as health administration (HA) compares nursing services across different wards and uses such comparatives for personnel planning. In an extended form, the PPR also influences the calculation of the nursing care complex measuring score (German: Pflegekomplexmaßnahmen-Score, PKMS) [17]. The PKMS was created by the German Board of Nursing (German: Deutsche Pflegerat) and triggers the OPS within the DRG calculation [18]: highly complex cases trigger their own OPS-code in the DRG system resulting in a cost-split and thereby generates an additional financial remuneration for the hospital.

\section{Basics in hospital leadership}

The hospital leadership consists of a chief executive officer (CEO) together with the human resource management (HRM), various Masters of Business Administration (MBAs), control-based and (CBM) and quality managements (QM). "The global management consulting market reached 133 billion US dollars in 2016 and it was expected to grow to 139 billion US dollars in 2017" [19]. One branch, HRM, promises to improve efficacy in management of organizations by taking care of staffing, training and development, motivation and maintenance thereby decreasing costs. The HRM market was recently estimated to reach "USD 30.0 billion by 2025" [20].

The MBA education contains a postgraduate management study with the prospects of bigger salaries and prestige. According to Professor Martin Parker of the University of Bristol, some 13000 business schools worldwide offer MBAs and various universities jumped aboard the train to profit by offering MBA programs with exaggerated tuitions [21]. Robert S. Rubin and Erich D. Dierdorff from DePaul University investigated "the relevancy of $M B A$ curricula in relation to managerial competency" and found "from 8633 incumbent managers across 52 managerial occupations...that behavioral competencies indicated by managers to be most critical are the very competencies least represented in required MBA curricula" [22].

Physicians still require studies that prove that quality management intended to generate standardized operative procedures (SOPs) improve life quality and/or even patient outcomes. Otherwise generating SOPs constrains already huge personal and financial resources. The medical community might start by asking the right questions with consequent investigations instead of creating paperwork. We doubt that there will someday be a SOP entitled "how to listen to a cancer patient'. Physicians and nurses increasingly question the value of excessive bureaucracy generated by QM, especially when scientific proof of benefit is lacking. The assumption that everything nurses and physicians do could be reduced to a QM-triggered SOP paper or computation is both egregious and erroneous.

Although the medical staff in hospitals is led by physicians, the $\mathrm{CEO}$ as senior administrator in hospitals has increasingly been filled by MBAs. In 2009, it was reported that out of 6500 hospitals within the US, 96.4\% were led by non-physicians with a $90 \%$ increase since 1935 while only $3.6 \%$ were led by physician administrators [23]. Amanda Goodall from Bonn, Germany, investigated the histories of 300 CEOs and found "a strong positive association between the ranked quality of a hospital and whether the CEO is a physician or not $(p<0.001)$ " [24]. Both findings were noted by the New York Times as the "overall hospital quality scores were about 25 percent higher when doctors ran the hospital, compared with other hospitals. For cancer care, doctor-run hospitals posted scores 33 percent higher" [25].

Increased HA in the US between 1975 and 2010 (Fig. 1)

Major parts of hospital management and HRM are represented by $\mathrm{CBM}$ and $\mathrm{QM}$. Both analyze hospital data and manage processes. It needs to be pointed out that this influences physician and nurse work days with various non-physician/-nurse - paper work. This, together, with the information discussed above may explain a disproportionate increase of Hospital Administrators (HA) within the US according to an Athena Health analysis of data from the Bureau of Labor Statistics, the National Center for Health Statistics, and the United States Census Bureau's Current Population Survey: an increase of $3200 \%$ within 35 years between 1975 and 2010 compared to $150 \%$ in practicing physicians (Fig. 1) [26]. These US data are not available for German healthcare. As transparent data are missing for Germany, we would assume that such data do not differ significantly.

\section{Economy - benchmarking (Figs. 2 and 3)}

Benchmarking is a tool in economics to evaluate qualitative analysis of services, products and methods so as to create a measure against with which to identify opportunities for improvement or performance gaps. In principle, the continuous evaluation can guide products, services and 


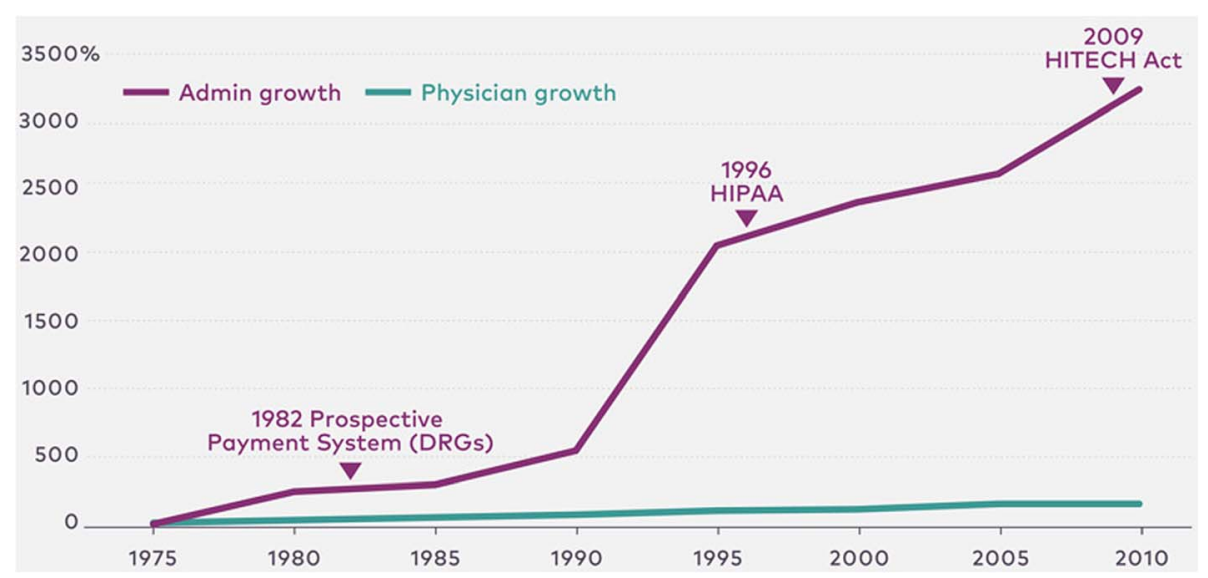

Figure 1. Healthcare administrator's growth in the US. Healthcare administrator's growth by $3200 \%$ between 1975 and 2010 compared to $150 \%$ Physician growth according to Athena Health analysis of data from Bureau of Labor Statistics, the National Center of Health Statistics, and the United States Census Bureau's Current Population survey in accordance to [26]. Admin: administration; HIPAA: Health Insurance Portability and Accountability Act; HITECH Act: Health Information Technology for Economic and Clinical Health Act; DRGs: diagnosis-related group's.

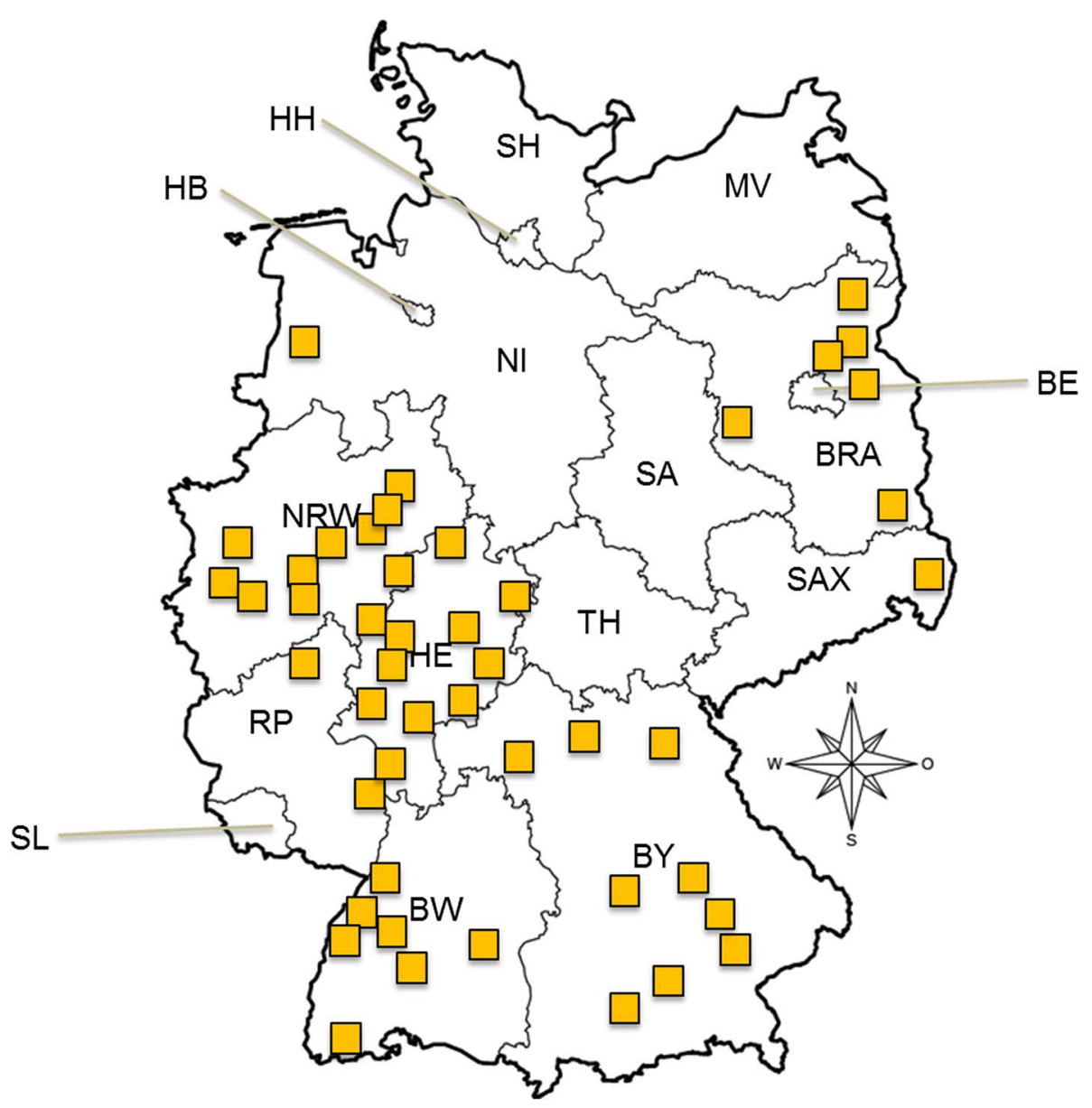

Figure 2. Representative for various hospitals in different Federal states in Germany by CLINOTEL. The highlighted points are representative for various hospitals in different Federal states in Germany by CLINOTEL [33]. Due not to declare which hospital may be less cost effective, the names of the hospitals were anonymized. BW: Baden-Wurttemberg; BY: Bavaria; BE: Berlin; BRA: Brandenburg; HB: Bremen; HH: Hamburg; HE: Hessen; MV: Mecklenburg-Vorpommern; NI: Lower Saxony; NRW: North RhineWestphalia; RP: Rheinland-Pfalz; SL: Saarland; SAX: Saxony; SA: Saxony-Anhalt; SH: Schleswig-Holstein; TH: Thuringia. 


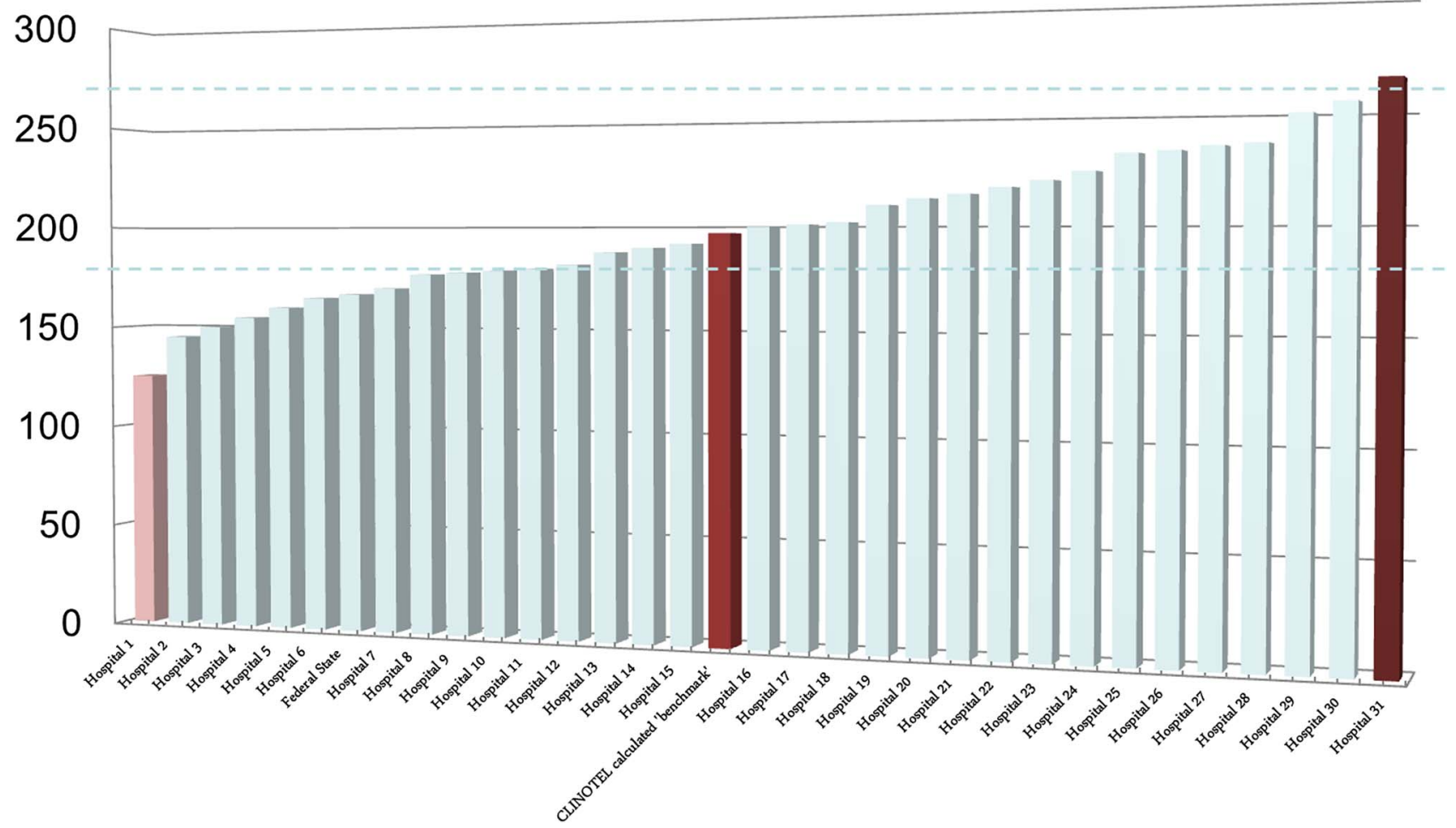

Figure 3. The CLINOTEL "benchmark" is the calculated effective cost weight (CW) (German: effektive Bewertungsrelation, BRW). The highlighted points are representative for various hospitals in different Federal states in Germany by CLINOTEL [33]. Due not to declare which hospital may be less cost effective, the names of the hospitals were anonymized.

practices by comparing a performance with the best from the strongest competitor or market leader. Although in use for a very long time, it is generally assumed that the term got the recognition it has after it was first adopted by the US company Rank Xerox (now: Xerox) in the 70s ([27-31] reviewed in [32]). During that time, Xerox was in a difficult economic situation. The Japanese competitor, Canon, introduced devices in the world market priced much lower than the production costs at Xerox. Therefore, a program "Leadership through quality" was established by Xerox together with employee motivation, and quality improvement using benchmarking for the improvement of the quality of its devices resulting in Xerox regaining its market leadership position.

In healthcare economics, benchmarking can make sense to improve efficiency for hospitals or medical device companies e.g. the evaluation of logistics in components needed for devices, use of goods for supply within a defined timeframe. During the introduction phase of the DRG system in Germany, hospitals agreed to participate in DRGbenchmarking to identify if the quality to code according to the DRG system was comparable to various hospitals or needed improvement. The intent was to improve DRG coding as this money for the hospitals was being received from insurance companies.

The resulting comparison of hospital beds in regard to size of the hospitals, numbers of patient treatment days, and length of hospital stay in days between hospitals yielded a calculated but still theoretical benchmark.
The primary argument was that it would provide information helpful to improve the quality for patient diagnosis and treatment. Indirectly, it resulted in the definition of a lower, mean, and upper DRG length of stay. At first, physicians and clinicians accepted this concept on good faith. Later the opposite occurred as the length of stay was continuously enforced by HA to be less than dictated by a patient's condition, but as this was also used to calculate the "optimal" medical staffing, with the consequence of decreased numbers of healthcare staff. A near collapse of hospitals across Germany almost happened. The numbers for physicians and how these kinds of calculations are performed are not easy to obtain but available. After serious protests, the numbers of physicians increased again but something different happened: if you cannot save money in the way on one profession, you decimate the next one and nursing bore the brunt such that their ranks dwindled year after year.

The goal of insurance as well as of the leadership of hospitals is to decrease patient stay in hospitals, to standardize payments of medical services of hospitals (principle: same price for same service), to decrease overcapacity in hospitals, and to limit future expected cost increases of inpatient diagnosis and treatment. To understand benchmarking in medicine, some examples are necessary.

When this kind of systematic "benchmarking" was adopted from the US, one major condition was never mentioned: increasingly global US comprehensive cancer centers (CCC) and/or concerns bought smaller hospitals, and patients were increasingly transferred early after major 
cancer surgery (with or without postoperative complications) to the smaller hospitals, but the reports of hospital stay only included the stay within the CCCs or concern hospitals. The artificially low numbers of hospital stays were aggressively demanded by insurance companies but now we live in a time in which this increasingly boomerangs as the primary variables did not comport with the reality. If we remind ourselves about the increase in elderly patients it is clear and even ridiculous to assume that a 86-year old patient after ultra-deep anterior rectal resection of transhiatal extended gastrectomy will be discharged somewhere on the 8th or 9th postoperative day, this also shows that readmission rates - declared as a "quality variable" - may be provided but not in the correct context. If a CCC patient after major cancer surgery was transferred early to a smaller hospital and discharged from it, the readmission rate to this hospital would never occur within the statistics of the CCC. By this kind of benchmarking, reality will not be displayed.

In 2018, some 62 hospitals with a budget of $€ 4.4$ billion, 1.2 million inpatient cases, 69000 employees and 2800 beds provided their data to CLINOTEL, which is an association of German hospitals so that these data could be analyzed to develop a new set of "benchmarks" [33]. Thus, CLINOTEL provides a "benchmarking" for the effective CWs between hospitals in the country, state and different counties as well.

If the effective CW is compared between hospitals (example of hospitals included in Fig. 2), it reveals how various hospitals differ compared to the CLINOTEL "benchmark" (Fig. 3). This is concordant with a hospital that has a lower effective CW means that the hospital earns less per physician compared to the CLINOTEL average. On the other hand, if a hospital is above the CLINOTEL benchmark, this reflects that the hospital earns a higher amount per physician (Fig. 3). So far, these data are officially not available for nurses, but the example already reveals that officially declared quality variables are unofficially used to save money.

\section{Benchmarking results: German healthcare market between 1994 and 2016 (Fig. 4)}

The consequences of benchmarking healthcare data happened over time. The German development of hospital beds in thousands, patient care treatment days, and treatment cases in millions, length of hospital stays in days, and number of births in thousands over a 22-year period between 1994 and 2016 are shown in Figure 4. These data are modified and completely actualized according to a prior partial analysis from 2011 [34].

Within this 22-year period, a decrease of 119000 hospitals beds, 43.1 million patient care treatment days, and length of hospital stays of 4.7 days were observed resulting in $19.3 \%, 23 \%$ and $39 \%$ of savings, respectively (Fig. 4). Simultaneously, an increase of 4.1 million treatment cases $(+26.5 \%)$ occurred. At the beginning of the 21st Century, a decrease of births in thousands occurred with an increase starting in 2012 until 2016. Although patient treatments increased by $26.5 \%$, significant savings in hospital beds, patient care, treatment days, and length of hospital stay was generated.

The term "benchmarking" was usurped by healthcare economics to save money and increase the profit of hospitals. In general, there is nothing is wrong with profits but creating profit for profit's sake and at the expense of patient care is associated with loss of focus, goals for humanity and even diminished ethics in healthcare. This may be termed as "profititis" as this inflammatory situation cannot be rectified unless the cause is not treated. A salient point that emerges from an understanding of benchmarking is that the German nursing shortage is triggered by "profititis" and, therefore, homemade.

This may even serve as an explanation why right now we live again (comparable to the situation of physicians decades ago) with the constant complaining by politicians, healthcare and hospital leaders and CEOs, as well as by nurse and physician organizations. Each day, week, month and year the complaining and statements asking that this situation be rectified continues, money is still saved, as the primary strategy of "profititis" triggered retrenchment and saving of personnel costs which was realized (see Fig. 4). The long-term effects - which might cause a secondary adverse situation in a decade is not of interest namely, the loss of professional recruitment to the nursing profession across Germany.

Benchmarking is an important instrument of strategic control to generate performance and save money under the cover of improvement of quality. However, it is quite of interest that there are no CLINOTEL data available to benchmark the efficiency of whether hospital administration and/or quality management improves healthcare of the German population? Furthermore, there was none and still is no proof that the creation of SOPs improves life quality of patients and/or prolongs patient survival.

Despite these economic perspectives understanding health care and money saving strategies, another important content needs a deeper exposition: documentation in hospital work.

\section{Documentation in hospital work}

Nurses (and physicians) are responsible by law for a certain amount of paperwork. There is the liability law approach enforced by the hospital leadership as well as professional insurances and only work, which is documented, will be reimbursed by health insurance companies. There is an increasing documentation for both nurses and physicians. Consequent data juggling forces professionals, both physicians and nurses, to adapt their course of medical action to economic conditions resulting in an undervalued risk that quantity comes to overrule quality. Specious argument of this game on data by CBM and HA was, and still is, to increase quality, but in reality, a different end point was realized.

The duty of documentation for nurses is increasingly seen to be critical as "Computer documentation in healthcare is notoriously inefficient and unwieldy, but an even more serious problem is that it has morphed into more than an account 
Hospital beds in thousands -119.000 beds
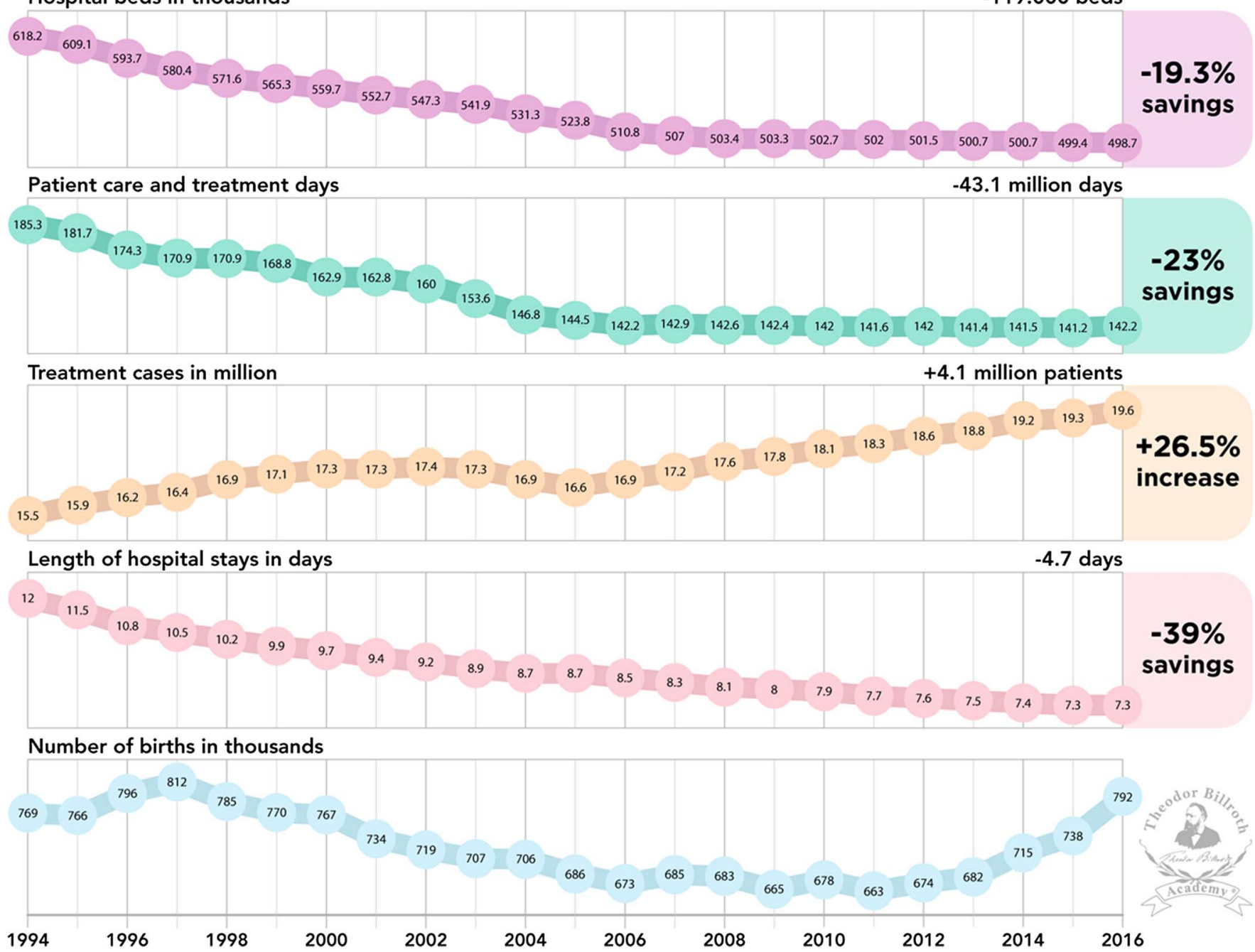

Figure 4. Development Hospital beds in thousands, patient care treatment days, treatment cases in millions, length of hospital stays in days, number of births in thousands in Germany during a 22-year time period between 1994 and 2016. These data are modified and completely actualized according to a prior partial analysis from 2011 [34].

of our work; it has replaced the work itself" [35]. The report of the Maryland Nursing Documentation Work Group reviewed in 2007 stated that "nurses spend from $25 \%$ of their time in the acute care setting - and up to $50 \%$ in home care environments - documenting care rather that delivering care directly to patients" ([36-38] reviewed in [39]).

In Germany, the Kassel declaration of a legal expert group in 2013 recommended the de-bureaucratization of nursing care documentation: the duty of documentation for nurses should only include the most important diagnostic and therapeutic procedures with the essentials [40]. However, this was not forwarded to the majority of nurses or nurse leadership in hospitals.

It cannot be explained why highly experienced and trained nurses (or physicians) in various sub-specialties should increasingly be burdened by unhelpful documentation. If these are mandatory, the documentation assistants in the section quality management should be attached to physicians and nurses and not to the administration.

\section{Nurse staffing and patient risk (Tab. 2)}

Needleman et al. "identified 14 adverse outcomes during hospitalization (11 for both medical and surgical patients and 3 for surgical patients only)" with consequent establishing coding rules and collected data from 11 US states in 1997 and 1998 [41]. After defining levels of staffing and risk adjustment the authors found that the mean number of "nursing care per patient-day was 11.4, of which 7.8 hours were provided by registered nurses, 1.2 hours by licensed practical nurses, and 2.4 hours by nurses' aides'. Patient care by registered nurses was associated with better patient care. Since outcome indicators have been elaborated for morbidity, e.g. such as venous thrombosis, nosocomial pneumonia, infection of the bladder or the operation wound, as well as decubitus, sepsis and mortality. Stargardt et al. showed in a retrospective analysis of 12284 patients with treatment for acute myocardial infarction between 2004 and 2006, that the hazard ratio of dying is 
Table 2. Variables for quality results associated with nurse personnel staffing numbers.

\section{Decubitus}

Urinary infections

Nosocomial pulmonary infections

Deep vein thrombosis

Gastritis and gastrointestinal bleeding

Sepsis

Cardiac arrest and shock

Neurological complications

Postoperative wound infections

Pulmonary insufficiency

Metabolic dysbalance

Mortality

associated by $+0.43 \%$ if a reduction of hospital costs by $€ 100$ - occurs [42].

The following variables have been reported to be used for quality of results and associated with nurse personnel staffing numbers and reviewed recently for the German government [43]: decubitus [40, 44-48], urinary infections [41, 44-50], nosocomial pulmonary infections [41, 44-48, $50,51]$, deep vein thrombosis [41,47-50], gastritis and gastrointestinal bleeding [41, 45, 47, 49], sepsis [41, 44-47, 51], cardiac arrest and shock [41, 45, 47-50], neurological complications [41, 45, 47-49], postoperative wound infections [41, 44, 47-49], pulmonary insufficiency [41, 46-51], metabolic disbalance [41, 47-49], and mortality [41, 51-55]. The variables for quality associated with nurse personnel staffing numbers are summarized in Table 2.

Controversies and limitations could be induced by various findings, missing risk adjustment, data acquisition and quality, inclusion and exclusion criteria, and analysis with interpretation. For example, analysis of intensive care unit (ICU) patients only is a challenge by themselves, as an objective risk adjustment is difficult to accomplish. The available data do not conform to each other: some authors found that patients admitted during night shifts were associated with an increased risk of dying [56]. A high-intensity daytime physician staffing at the ICU was reported to be not associated with a mortality decrease [57] while others found that risk only in a sub-population with a weak increase of HR (1.21) [58] or even associated with nurse shortage [59].

One major risk factor for patients admitted during night shifts was seen in the variation of late arrival of ambulances during night shifts [60]. However, a lower mortality by about $33 \%$ and decrease of patient costs has been clearly shown [61, 62], and increasing nursing numbers results in an increase of patient protection, decrease of patient's postoperative morbidity and overall mortality, decrease of readmission rates plus increase of patient and employer satisfaction with enlarged staff retention [63]. Furthermore, it was shown, that shortchanging nurses results in a doubling of sick days compared to physicians [64] as the nursing shortage affects employee health negatively. In summary, enforcing nursing shortage is not just a myopic economicdriven view, it risks patient and employee health.

\section{Nursing in Germany}

In the following section we focus on examined/registered nurses responsible for hospital healthcare and did not comingle these with nurses in geriatric nursing, assistants in nursing and/or geriatric nursing.

\section{Numbers of nurses in Germany}

Professor Dr. Michael Simon showed in 2012 that the often-declared growth of nursing employment in Germany is in reality much lower (1.21 million) compared to official statistics of all nurse employees (1.46 million) revealing a difference of $20 \%$ ( $n=200000)$ [18]. Predominantly, an expansion of part-time employment was observed. Therefore, a more nuanced perspective is necessary (Tab. 3).

Nationwide, an increase in number of nurses occurred $(+23 \%)$, but it is inappropriate to include in such a number those nurses who work in hospitals $(-0.4 \%)$ together with nurses employed in preventive and rehabilitation facilities $(+15.1 \%)$ and/or in outpatient care facilities $(+41.1 \%)$ and/or nursing homes $(+24.8 \%)$ and/or nurses working in retirement homes $(+77.9 \%)$. In summary, the reality is that the numbers of registered nurses in hospitals have decreased (Tab. 3) although a significant increase in patient cases occurred (see for this Fig. 4). Simon further showed, that the number of part-time workers increased by about $60 \%$ (data not shown). This reveals that arguments such as "we have enough nurses in hospitals as the market is growing" are incorrect. The real numbers of nurses working in hospitals have decreased and in fact a downsizing of nurse care jobs in hospitals has occurred.

\section{Nursing staffing in other countries \\ Nurse staffing in Germany compared to various European countries and the US (Tab. 4)}

It comes as no accident that countries with excellence in patient care have about 3.6-5.0 patients treated per nurse compared to 7.2-10.5 in Poland, Belgium and Germany [65]. We would argue that it is just a matter of time when the risk overrules economic thinking of HA.

In Australia, a minimum nurse staffing was established in 2000 in Victoria and 2015 and 2016 in Queensland contingent on early, late and night shifts [63, 66-68]. The staffing is also influenced and based on whether patients are treated in departments with severe versus moderate or low patient comorbidity and/or disease profiles. It is known that intrinsic motivation influences postgraduate specialty programs [69], but so far information of mental state and/or intrinsic motivation on patient outcome in this regard are still warranted. The California perspectives has been modified due to the knowledge of nursing shortage association with decreased patient safety and outcome [70-73].

The numbers above, as well as the available data, clearly show that better nurse staffing numbers improve 
Table 3. Numbers of nurses in Germany.

\begin{tabular}{|c|c|c|c|c|c|c|c|c|}
\hline \multirow[t]{2}{*}{ Variable } & \multirow[t]{2}{*}{1999} & \multirow[t]{2}{*}{2001} & \multirow[t]{2}{*}{2003} & \multirow[t]{2}{*}{2005} & \multirow[t]{2}{*}{2007} & \multirow[t]{2}{*}{2009} & \multicolumn{2}{|c|}{ Development } \\
\hline & & & & & & & Numbers & Percentage \\
\hline $\begin{array}{l}\text { Total numbers of employee's } \\
\text { working in nursing professions }\end{array}$ & 870949 & 907266 & 944936 & 973495 & 1012841 & 1070842 & +199893 & +23 \\
\hline $\begin{array}{l}\text { Among that employee's with } \\
\text { completed nursing studies }\end{array}$ & 1228 & 1631 & 1954 & 2291 & 5204 & 4706 & +2478 & +202 \\
\hline Nurses with 3-year education & 606019 & 629638 & 655211 & 676533 & 705872 & 729655 & +123636 & +20.4 \\
\hline $\begin{array}{l}\text { In \% of total nurse } \\
\text { numbers }\end{array}$ & 69.6 & 69.4 & 69.3 & 69.5 & 69.7 & 68.1 & -1.4 & -2.1 \\
\hline $\begin{array}{l}\text { Among those, nurses } \\
\text { working in hospitals }\end{array}$ & 325539 & 329980 & 326202 & 316692 & 317619 & 324337 & -1202 & -0.4 \\
\hline $\begin{array}{l}\text { Among those, nurses working } \\
\text { in outpatient care facilities }\end{array}$ & 58144 & 57457 & 63233 & 71425 & 78184 & 82055 & +23911 & +41.1 \\
\hline $\begin{array}{l}\text { Among those, nurses working } \\
\text { in nursing homes }\end{array}$ & 47300 & 49330 & 55348 & 61238 & 61519 & 59054 & +11754 & +24.8 \\
\hline Pediatric nurses & 48546 & 49066 & 49621 & 49261 & 49859 & 50073 & +1527 & +3.1 \\
\hline $\begin{array}{l}\text { Among those, nurses working } \\
\text { in hospitals }\end{array}$ & 40514 & 40502 & 39875 & 38446 & 37789 & 37557 & -2957 & -7.3 \\
\hline Geriatric nurses & 109161 & 124879 & 141965 & 158817 & 178902 & 194195 & +85034 & +77.9 \\
\hline
\end{tabular}

Data according to the Board of Nursing (German: Deutscher Pflegerat) [18].

patient survival and outcome are not just available for comparison of the US with Europe [74-76], such data are available for various countries [77].

The real interesting point in California calculations were the follow-up calculations and step-by-step modifications [76-89]. Such a long-term goal of continuous research of patient outcome together with professional satisfaction is urgently needed in Europe for every country in terms of nurses and physicians.

Clinical practice guidelines defined "by the Institute of Medicine as systematically developed statements to assist practitioner and patient decisions about appropriate health care for specific clinical circumstances...to improve the quality of patient care" [90-93]. However, if we increase consistently the SOPs in hospitals with the attempt to increase quality and patient care, together with economic-driven nursing shortages, the primary intent of clinical guidelines seems absurd.

\section{Solution by law?}

A 2018 survey of more than 3000 German nurses by the newspaper Die Zeit and the television program ARD Report revealed that $86 \%$ of nurses complain that they could not adequately care for their patients, $85 \%$ could not keep their breaks, $80 \%$ could not even comply with the hygiene
Table 4. Comparison of nurse staffing of Germany with various European countries and the US according to [65].

\begin{tabular}{lcc}
\hline Country & $\begin{array}{c}\text { Number of patients } \\
\text { per nurse (examined plus } \\
\text { assistants in nursing) }\end{array}$ & $\begin{array}{c}\text { Number of } \\
\text { patients per } \\
\text { examined nurse }\end{array}$ \\
\hline Germany & 10.5 & 13.0 \\
Belgium & 7.9 & 10.7 \\
Poland & 7.2 & 10.5 \\
Spain & 6.8 & 12.6 \\
Greece & 6.2 & 10.2 \\
Finland & 5.3 & 8.3 \\
Ireland & 5.0 & 6.9 \\
Netherland & 5.0 & 7.0 \\
Switzerland & 5.0 & 7.9 \\
Sweden & 4.2 & 7.7 \\
Norway & 3.3 & 5.4 \\
US & 3.6 & 5.3 \\
\hline
\end{tabular}

guidelines and $75 \%$ already had filed an official overload letter to their HA [94].

This reveals that too many patients are treated by one nurse (registered plus assistants in nursing) or per registered nurses. As provided in Table 4, too many patients are treated by a single nurse. This is "the" main problem, meaning, although profits are generated by patient numbers, decrease of patient's beds, etc., too many patients are treated by a 
single nurse as provided in Table 4 . In this regard, declaring additional 13000 jobs for nurses in retirement homes will not resolve the dire situation in hospitals. In this regard it is necessary to mention, that anesthetists demanded a necessary patient-nurse-relation at intensive care units (ICU) [95], which is still ignored.

However, the German personnel lower limit regulation (Pflegepersonaluntergrenzen-Verordnung, PpUVG) has been responsible since January 1, 2019 (came into force on October 11, 2018) by the German Federal Ministry of Health [96]. The new law stipulates that nurse will be relieved by an increase of digitalization. However, the ones who will perform the documentation of the data will be still nurses and physicians meaning no relief can be expected. Furthermore, there are no studies or randomized trials proving that any kind of digitalization improves nursing and/or physician and/or patient satisfaction and/or quality. This means there is no proof that hospital professions such as nurses or physicians will be relieved by digitalization proposed by the law.

Each additional nurse position at hospitals will in the future have to be financed completely by the payers (GKV and PKV) in order to improve the staffing in healthcare. However, it is dubious that financing of nurse's workplaces will be done by the insurance companies. Insurance companies have no interest in doing so, as the insurances already have a proven billion Euro surplus, but here it has also been declared, that new financing should be "cost-neutral". This declaration "cost-neutral" financing means that money to finance nursing staffing should be taken away and no additional money will be invested to fund an increase of nurses and/or the relation nurse per patient as needed in hospitals.

As it is also planned that the training allowance for trainees in pediatric nursing, nursing and nursing assistance should be fully financed by the insurance companies as well - under the circumstances that this already had been declared to be cost-neutral - nurses, physicians and associations already ask themselves how the new financing will occur in reality.

There is the plan that the financing of nursing staff costs of hospitals will be converted from 2020 to a new, independent of the case flat rates, hospital-individual compensation. Furthermore, the nursing equipment should be regulated on the basis of a "nursing quotient" from 2020. Both suggest that even now no acute solution is on the horizon (again). Health insurance companies do not want to finance the above-suggested variables, although until now the number of gains by health insurances has increased above $€ 20$ billion [97].

This explains, why it seems, that a declared protective coat of modernization with increase of nursing numbers and especially - as highly recommended and needed - the numbers of patients treated by nurses in hospitals have urgently been to regulate in between 6 and 7. Any other proposed solution will not be a short- or a middle- or a long-term solution. Furthermore, no cost-neutral solution will be successful meaning that the new law only would be a bureaucratic instrument. In addition, one wonders how the already exorbitant administrative burden to be financed with the now considerable additional administrative personnel expenses. And no reporting center has been implemented in which daily and shift-related under runs must be officially reported. Unfortunately, this law does not counteract the chronic overwork of nurses. This means, nurses as employers and humans as well as patients are - still - at risk.

\section{Summary}

Nursing shortage during the last few decades in Germany is a result of profititis and, therefore, is homemade. A physician is nothing without a nurse and vice versa. The reputation and value of each single university, hospital, administration, physician, and nurse is inseparable from individuals and its employers. This even influences the reputation and quality of a city, state, and country. Ignoring facts in patient care together with continuing the trend of nursing staff shortage and repetitive declarations from administration or even politics points of view reveals a lack of leadership as the basics in management, leadership and ethics are misinterpreted. Arthur Schoppenhauer's quote is already internalized: "The greatest folly is to sacrifice his health" (German: Die größte Torheit ist, seine Gesundheit aufzuopfern). By German law, delictively protected legal interest are, in particular life, the body, health, freedom and property according to $\S 823$ Abs. 1 BGB. Patients, politics and administration expect if something goes wrong, that clinicians act appropriately. We would argue that it is urgent to take responsibility in regard of staff and nursing shortage - now.

Furthermore we may remind us, that continuous savings during the last decades had been generated with simultaneously increased revenues. Figure 4 does not just explain how moneymaking in healthcare economic influenced not only personnel costs by nursing shortage in Germany. This even can be transformed to other professions in healthcare, such as physicians, secretaries, typists, technicians. Although we did not investigate it within this analysis, the results reviewed may serve as an explanation for an increase of working time compression which furthermore results into dissatisfaction and less professional attractiveness.

In accordance with the Berlin Association of Statutory Health Insurance Physicians, German health care will lack some 6300 physicians until 2030 [98]. This supply gap in German healthcare will be simultaneously increased by nursing shortage rates. According to the Bertelsmann Foundation, the percentage rate of patients in need of care will increase until 2030 by about $50 \%$ under with the assumption that age and sex-specific rates would constant during the next two decades [99]. In Germany, staff shortage occurred in parallel during the 90s with decreasing physician rates. History repeated itself: now once more by a severe nursing shortage. Equally this again endangers again - patient care and profession attractiveness as profit gear with profititis occurred. The consequences out of this were only striped here. 
Just imagine how community hospitals do not perform science and research anymore due to the economic pressure. But it seems to be forgotten, that some $80 \%$ of cancer patients are treated not in center of excellences, such are treated in general hospitals which alone shows the necessity of health service research which undermines the necessity taking care of its employers in the right way. It is unfortunate, but that means, that there is already an increasing loss of scientific clinical work in community hospitals compared to Universities and small hospitals even get much less consideration. This already resulted into loss of knowledge and ability together with increasing lack of influence on patient treatment.

\section{Nomenclature of abbreviations (used in the text and the figure)}

\begin{tabular}{|c|c|}
\hline Admin & Administration \\
\hline AR-DRG & $\begin{array}{l}\text { Australian Refined Diagnosis Related } \\
\text { Groups }\end{array}$ \\
\hline BW & Baden-Wurttemberg \\
\hline BY & Bavaria \\
\hline $\mathrm{BE}$ & Berlin \\
\hline $\mathrm{BR}$ & Base rate, German: Basisfallwert \\
\hline BRA & Brandenburg \\
\hline BWR & German: Bewertungsrelation, cost weight \\
\hline $\mathrm{CBM}$ & Control-based management \\
\hline $\mathrm{CCC}$ & Comprehensive cancer center \\
\hline $\mathrm{CEO}$ & Chief executive officer \\
\hline CW & $\begin{array}{l}\text { Cost weight, German: } \\
\text { Bewertungsrelation, BWR }\end{array}$ \\
\hline DKG & $\begin{array}{l}\text { German Hospital Society, German: } \\
\text { Deutsche Krankenhausgesellschaft }\end{array}$ \\
\hline DRG & Diagnosis-related group \\
\hline GKV & $\begin{array}{l}\text { Association of health insurance } \\
\text { companies, German: Spitzenverband } \\
\text { Bund der Krankenkassen }\end{array}$ \\
\hline $\mathrm{HA}$ & Hospital administration \\
\hline $\mathrm{HB}$ & Bremen \\
\hline $\mathrm{HH}$ & Hamburg \\
\hline $\mathrm{HE}$ & Hessen \\
\hline HIPAA & $\begin{array}{l}\text { Health Insurance Portability and } \\
\text { Accountability Act }\end{array}$ \\
\hline HITECH Act & $\begin{array}{l}\text { Health Information Technology for } \\
\text { Economic and Clinical Health Act }\end{array}$ \\
\hline HRM & Human resource management \\
\hline $\mathrm{IAB}$ & $\begin{array}{l}\text { Institute for Employment Research, } \\
\text { German: Institut für Arbeitsmarkt- und } \\
\text { Berufsforschung }\end{array}$ \\
\hline $\mathrm{ICU}$ & Intensive care unit \\
\hline InEK & $\begin{array}{l}\text { Institute for Remuneration System in } \\
\text { Hospitals, German: Institut für das Ent- } \\
\text { geltsystem im Krankenhaus in Siegburg }\end{array}$ \\
\hline KHG & $\begin{array}{l}\text { Hospital Financing Act, German: } \\
\text { Krankenhausfinanzierungsgesetz }\end{array}$ \\
\hline
\end{tabular}

$\begin{array}{ll}\text { MBA } & \text { Master of business administration } \\ \text { MV } & \text { Mecklenburg-Vorpommern } \\ \text { NI } & \text { Lower Saxony } \\ \text { NRW } & \text { North Rhine-Westphalia } \\ \text { OPS-code } & \text { Operationen- } \text {-nd Prozedurenschlüssel } \\ \text { QM } & \text { Quality management } \\ \text { PKMS } & \text { Nursing care complex measuring score, } \\ & \text { German: Pflegekomplexmaßnahmen- } \\ & \text { Score PKMS } \\ \text { PKV } & \text { Private health insurance, German: } \\ & \text { Verband privater Krankenkassen } \\ \text { PPR } & \text { Nurse staff regulation, German: } \\ & \text { Pflegepersonalregelung } \\ \text { PpUVG } & \text { Pflegepersonaluntergrenzen-Verordnung } \\ \text { RP } & \text { Rheinland-Pfalz } \\ \text { SAX } & \text { Saxony } \\ \text { SA } & \text { Saxony-Anhalt } \\ \text { SH } & \text { Schleswig-Holstein } \\ \text { SOP } & \text { Standardized operative procedure } \\ \text { SL } & \text { Saarland } \\ \text { TH } & \text { Thuringia } \\ \text { WHO } & \text { World Health Organization }\end{array}$

\section{Conflict of interest}

The author reports the following conflict of interest: Björn LDM Brücher is Editor-in-Chief in Life SciencesMedicine of 4open by EDP Sciences. Daniela Deufert is Editorial Board members in Life Sciences-Medicine of 4 open by EDP Sciences. The authors, of their own initiative, suggested to the Managing Editorial to perform a transparent peer-review of their submittals. Neither author took any action to influence the standard submission and peer-review process, and report no conflict of interest. The authors alone are responsible for the content and writing of the manuscript of this Special Issue. This manuscript contains original material that has not previously been published. All authors contributed on its contents and approved the different manuscript.

\section{Acknowledgments}

The manuscripts were supported by the TheodorBillroth-Academy ${ }^{\circledR}\left(\mathrm{TBA}^{\circledR}\right)$ and INCORE (International Consortium of Research Excellence) of the $\left(\mathrm{TBA}^{\circledR}\right)$. We express our gratitude to the discussions on the web group of the Theodor-Billroth-Academy ${ }^{\circledR}\left(\mathrm{TBA}^{\circledR}\right)$ on LinkedIn, the exchange with scientists at Researchgate.com, as well as personal exchanges with distinguished colleagues who stimulated our thinking all named individually earlier in publications - we thank each one. We further gratefully acknowledge the support of Günter Neubauer, Director of the Institute of Health Economics (IfG), Munich, Germany, for pre-submission review and our fruitful discussions. 


\section{References}

1. United Nations (2017), From 1950 to current year: elaboration of data by United Nations, Department of Economic and Social Affairs, Population Division. World Population Prospects: The 2017 Revision. http://www.worldometers. info/world-population/

2. World Health Organization (2014), "Ageing well" must be a global priority. http://www.who.int/mediacentre/news/ releases/2014/lancet-ageing-series/en/ (access November $6,2014)$.

3. Brücher BLDM (2018), Science belongs to no one - and to everyone. 4open 1, E1, 1-11.

4. Pagano M (2017), Don't run biomedical science as a business. Nature 547, 381. https://www.nature.com/ news/don-t-run-biomedical-science-as-a-business- 1.22366

5. Statistisches Bundesamt (Destatis) (2017), Gesundheit, Grunddaten der Krankenhäuser. https://www-genesis. destatis.de (access June 16, 2018).

6. Deutsche Krankenhausgesellschaft (DKG) (2017), Eckdaten der Krankenhausstatistik. https://www.dkgev.de/media/ file/64821.Eckdaten_Krankenhausstatistik_Stand_201710-05.pdf

7. Codman EA (1913-1917), The product of a hospital (Philadelphia address) (Box 4, Folder 77) in Codman EA, Ernest Amory Codman, Papers, 1849-1981: Finding Aid. Boston Medical Library and Francis A, Countway Library of Medicine (B MS c60), Boston, MA.

8. Fetter RB, Shin Y, Freeman JL, Averill RF, Thompson JD (1980), Case mix definition by diagnosis related groups. Medical Care 18, 2, 1-53.

9. Fetter RB (Ed.) (1991), DRGs: their design and development, Health Administration Press, Ann Arbor, MI.

10. Chilingerian J (2008), Origins of DRGs in the United States: A technical, political and cultural story, in: J. Kimberly, G. de Pouvourville, T. d'Aunno (Eds.), The globalization of managerial innovation in health care, Cambridge University Press, Cambridge, pp. 4-33.

11. Mayes R (2007), The Origins, Development, and Passage of Medicare's Revolutionary Prospective Payment System. J Hist Med Allied Sci 62, 1, 21-55.

12. Eversmeyer M (2001), Das DRG-System stoppt in Australien nicht den Ausgabenanstieg. F \& W, Führen und Wirtschaften im Krankenhaus 3, 230-232.

13. Vera A (2009), Die "Industrialisierung" des Krankenhauswesens durch DRG-Fallpauschalen - eine interdisziplinäre Analyse. Gesundheitswesen 71, 3, e10-e17.

14. Busse E, Geissler A, Quentin W, Wiley M (2011), Diagnosis related groups in Europe, moving towards transparency, efficiency and quality in hospitals, McGraw Hill, Open University Press, World Health Organization 2011 on behalf of the European Observatory on Health Systems and Policies, Berkshire, UK, ISBN-13: 978-0-33-524557-4, pp. 1-475.

15. Busse R, Geissler A, Aaviksoo A, Cots F, Häkkinen U, Kobel C, Mateus C, Or Z, O'Reilly J, Serdén L, Street A, Tan SS, Quentin W (2013), Diagnosis related groups in Europe: moving towards transparency, efficiency, and quality in hospitals? BMJ 7, 346, f3197.

16. Gesundheitsstrukturgesetz (1992), http://www.gesetze-iminternet.de/gsg/index.html

17. Institut für das Entgeltsystem im Krankenhaus InEK (2010), Kalkulationen PPR für Behandlungsfälle mit hochaufwendiger Pflege, June 7, 2010, https://www.g-drg.de/

18. Simon M (2012), Beschäftigte und Beschäftigungsstrukturen in Pflegeberufen, Eine Analyse der Jahre 1999 bis
2009, Studie für den Deutschen Pflegerat. pp. 1-70. http:// www.dpo-rlp.de/simon_besch_-und-besch_stru.pdf

19. Statista (2018), Management consulting market size by sector from 2011 to 2020 (in billion US dollars). https:// www.statista.com/statistics/466460/global-managementconsulting-market-size-by-sector/ (access June 16, 2018).

20. Grand View Research (2018), Human Resource Management (HRM) Market Size, Share \& Trend Analysis Report By Software, By Service, By Deployment (Hosted, Onpremise), By Enterprise Size (Large Enterprise, SMEs) By End Use, And Segment Forecasts, 2018-2025. https:// www.grandviewresearch.com/industry-analysis/humanresource-management-hrm-market (access June 16, 2018).

21. Parker M (2018), Why we should bulldoze the business school. The Guardian. April 27, 2018, https://www.theguardian.com/ news/2018/apr/27/bulldoze-the-business-school

22. Rubin RS, Dierdorff ED (2009), How relevant is the MBA? Assessing the alignment of required curricula and required managerial competencies Acad Manag Learn Educ 8, 2, 208-224.

23. Gunderman R, Kanter SL (2009), Perspective: Educating physicians to lead hospitals. Acad Med 84, 10, 1348-1351.

24. Goodall AH (2011), Physician-leaders and hospital performance: Is there an association? Soc Sci Med 73, 4, 535-539.

25. Parker-Pope T (2011), Should hospitals be run by doctors? The New York Times. July 7, 2011. https://well.blogs. nytimes.com/2011/07/07/should-hospitals-be-run-by-doctors/ (access June 16, 2018).

26. Cantlupe J (2017), The rise (and rise) of the healthcare administrator. November 7, 2017. https://www. athenahealth.com/insight/expert-forum-rise-and-rise-healthcare-administrator (access June 16, 2018).

27. Camp RC (1983), Benchmarking: The search for industry best practices that lead to superior performance, American Society of Quality Control (ASQC), Quality Press, Milwaukee, Wisconsin.

28. Rank Xerox Ltd (1992), European Quality Award, Vision, House magazine of Rank Xerox Mitcheldean, https:// memoriesofrxmp.info/wp-content/uploads/2017/08/ Vision-216-Nov_Dec-1992.pdf

29. Rank Xerox (1992), European Quality Award, 1992 Rank Xerox. ASQ Quality Press Publisher, Milwaukee, Wisconsin, ISBN-10:0873892925.

30. Bemowski K (1991), The benchmarking bandwagon. Qual Prog 24, 1, 19-24.

31. Horvath P, Herter RN (1992), Benchmarking. Vergleich mit dem Besten der Besten. Controlling 4, 1, 4-11.

32. Cross R, Iqbal A (1995), The Rank Xerox experience: Benchmarking ten years on, in: A. Rolstadas (Ed.), Benchmarking - Theory and practice, IFIP advances in information and communication technology, Springer, Boston, MA.

33. CLINOTEL (2018), https://www.clinotel.de (access June $16,2018)$

34. Neubauer G (2011), Ein Jahrzehnt Gesundheitsökonomie und Gesundheitspolitik 2000-2010, Band II, IfG, Institut für Gesundheitsökonomik, München, Deutschland.

35. Brown T (2015), Too much paperwork, too little time for patients. The Straits Times, International Edition. December 21, 2015. https://www.straitstimes.com/opinion/too-muchpaperwork-too-little-time-for-patients

36. Pabst MK, Scherubel JC, Minnick AF (1996), The impact of computerized documentation on nurses' use of time. Comput Nur 14, 1, 25-30.

37. Korst LM, Eusebio-Angeja AC, Chamorro T, Aydin CE, Gregory KD (2003), Nursing documentation time during 
implementation of an electronic medical record. J Nur Adm $33,1,24-30$.

38. Epps-Reaid C (2001), Reduction of unnecessary or duplicative documentation and paperwork, Georgia Nursing, August-October.

39. Gugerty B, Maranda MJ, Navarro VB, Newbold S, Hawk W, Karp J, Koszalka M, Morrison S, Poe SS, Wilhelm D (2007), Challenges and opportunities in documentation of the nursing care of patients, Documentation Work Group, Maryland Nursing Workforce Commission, Baltimore. pp. 1-28, http://www.mbon.org/commission2/documentation_ challenges.pdf.

40. Juristische Expertengruppe Entbürokratisierung der Pflegedokumentation (2014). http://www.ein-step.de/fileadmin/ content/documents/Kasseler_Erklaerung_Pflegedoku_ HaftR_21_01_2014.pdf (access June 16, 2018).

41. Needleman J, Buerhaus P, Mattke S, Stewart M, Zelevinsky K (2002), Nurse-staffing levels and the quality of care in hospitals. N Engl J Med 346, 22, 1715-1722.

42. Stargardt T, Schreyögg J, Kondofersky I (2014), Measuring the relationship between costs and outcomes: The example of acute myocardial infarction in German hospitals. Health Econ 23, 6, 653-669.

43. Schreyögg J, Milstein R (2016), Expertise zur Ermittlung des Zusammenhangs zwischen Pflegeverhältniszahlen und pflegesensitiven Ergebnisparametern in Deutschland, im Auftrag des Bundesministeriums für Gesundheit (BMG), https:// www.bundesgesundheitsministerium.de/fileadmin/Dateien/ 5_Publikationen/Pflege/Berichte/Gutachten_Schreyoegg Pflegesensitive Fachabteilungen.pdf

44. Cho $\overline{\mathrm{S}} H$, Ketefian S, Barkauskas VH, Smith DG (2003), The effects of nurse staffing on adverse events, morbidity, mortality, and medical costs. Nurs Res 52, 2, 71-79.

45. Mattke S, Needleman J, Buerhaus P, Stewart M, Zelevinsky K (2004), Evaluating the role of patient sample definitions for quality indicators sensitive to nurse staffing patterns. Med Care 42, Suppl 2, II21-33.

46. Weissman JS, Rothschild JM, Bendavid E, Sprivulis P, Cook EF, Evans RS, Kaganova Y, Bender M, DavidKasdan J, Haug P, Lloyd J, Selbovitz LG, Murff HJ, Bates DW (2007), Hospital workload and adverse events. Med Care 45, 5, 448-455.

47. Carryer JB, Diers D, McCloskey B, Wilson D (2010), Effects of health policy reforms on nursing resources and patient outcomes in New Zealand. Policy Polit Nurs Pract 11, 4, 275-285.

48. Twigg DE, Gelder L, Myers H (2015), The impact of understaffed shifts on nurse-sensitive outcome. J Adv Nurs $71,7,1564-1572$.

49. Twigg D, Duffield C, Bremner A, Rapley P, Finn J (2011), The impact of the nursing hours per patient day (NHPPD) staffing method on patient outcomes: a retrospective analysis of patient and staffing data. Int J Nurs Stud 48, 5, 540-548.

50. Kovner C, Jones C, Zhan C, Gergen PJ, Basu J (2002), Nurse staffing and postsurgical adverse events: an analysis of administrative data from a sample of US hospitals, 19901996. Health Serv Res 373, 611-629.

51. Kane RL, Shamliyan TA, Mueller C, Duval S, Wilt TJ (2007), The association of registered nurse staffing levels and patient outcomes: systematic review and meta-analysis. Med Care 45, 12, 1195-1204.

52. Aiken LH, Clarke SP, Sloane DM, Sochalski J, Silber JH (2002), Hospital nurse staffing and patient mortality, nurse burnout, and job dissatisfaction. JAMA 288, 16, 1987-1993.
53. Aiken LH, Clarke SP, Cheung RB, Sloane DM, Silber JH (2003), Educational levels of hospital nurses and surgical patient mortality. JAMA 290, 12, 1617-1623.

54. Needleman J, Buerhaus P, Pankratz VS, Leibson CL, Stevens SR, Harris M (2011), Nurse staffing and inpatient hospital mortality. N Engl J Med 364, 11, 1037-1045.

55. Aiken LH, Sloane DM, Bruyneel L, Van den Heede K, Griffiths P, Busse R, Diomidous M, Kinnunen J, Kózka M, Lesaffre E, McHugh MD, Moreno-Casbas MT, Rafferty AM, Schwendimann R, Scott PA, Tishelman C, van Achterberg T, Sermeus W, RN4CAST consortium (2014), Nurse staffing and education and hospital mortality in nine European countries: a retrospective observational study. Lancet 383, 9931, 1824-1830.

56. Goldfrad C, Rowan K (2000), Consequences of discharges from intensive care at night. Lancet 355, 9210.

57. Costa DK, Wallace DJ, Kahn JM (2015), The Association Between Daytime Intensivist Physician Staffing and Mortality in the Context of Other ICU Organizational Practices: A Multicenter Cohort Study. Crit Care Med 43, $11,2275-2282$

58. Meacock R, Anselmi L, Kristensen SR, Doran T, Sutton M (2017), Higher mortality rates amongst emergency patients admitted to hospital at weekends reflect a lower probability of admission. J Health Serv Res Policy 22, 1, 12-19.

59. Bell CM, Redelmeier DA (2001), Mortality among patients admitted to hospitals on weekends as compared with weekdays. N Engl J Med 345, 663-668.

60. Anselmi L, Meacock R, Kristensen SR, Doran T, Sutton M (2017), Arrival by ambulance explains variation in mortality by time of admission: retrospective study of admissions to hospital following emergency department attendance in England. BMJ Qual Saf 268, 613-621.

61. Hickey PA, Gauvreau K, Jenkins K, Fawcett J, Hayman L (2011), Statewide and national impact of California's Staffing Law on pediatric cardiac surgery outcomes. J Nurs Adm 41, 5, 218-225.

62. Aiken LH (2010), The California nurse staffing mandate: Implications for other states. LDI Issue Brief 15, 4, 1-4.

63. Queensland Department of Health (2015) Hospital and Health Boarders Amendment Bill 2015. https://www. health.qld.gov.au/system-governance/legislation/reviews/ mental-health

64. Neubauer G (2013), Patient gesund - Mitarbeiter krank. Personalwirtschaft - Magazin für Human Resources, Spezial Gesundheitsbranche, Extra 2013, 18-20. http://www. siemann.net/wp-content/uploads/Persomalmanagementim-Krankenhaus.pdf

65. Aiken LH, Sermeus W, Van den Heede K, Sloane DM, Busse R, McKee M, Bruyneel L, Rafferty AM, Griffiths P, Moreno-Casbas MT, Tishelman C, Scott A, Brzostek T, Kinnunen J, Schwendimann R, Heinen M, Zikos D, Sjetne IS, Smith HL, Kutney-Lee A (2012), Patient safety, satisfaction, and quality of hospital care: cross sectional surveys of nurses and patients in 12 countries in Europe and the United States. BMJ 344, e1717.

66. Australian Nursing \& Midwifery Federation (ANMF) (2014), Nurse/Midwife: Patient ratios. It's a matter of saving lives, Australian Nursing \& Midwifery Federation (ANMF), Melbourne.

67. Queensland Department of Health (2015), Hospital and Health Boards (Safe Nurse-to-Patient and Midwife-to-Patient Ratios). Amendment Bill 2015, pp. 1-4. https:// cabinet.qld.gov.au/documents/2015/Nov/PatientRatiosBill/ Attachments/ExNotes.PDF. 
68. State of Queensland (2016) Hospital and health boards amendment regulation, subordinate legislation 2016, No. 106 made under the Hospital and Health Boards Act 2011.

69. Kinsella D, Fry M, Zecchin A (2018), Motivational factors influencing nurses to undertake postgraduate hospital-based education. Nurse Educ Pract 31, 54-60.

70. Donaldson N, Bolton LB, Aydin C, Brown D, Elashoff JD, Sandhu M (2005), Impact of California's licensed nursepatient ratios on unit-level nurse staffing and patient outcomes. Policy Polit Nurs Pract 6, 3, 198-210.

71. Aiken LH, Sloane DM, Cimiotti JP, Clarke SP, Flynn L, Seago JA, Spetz J, Smith HL (2009), Implications of the California nurse staffing mandate for other states. Health Serv Res 45, 4, 904-921.

72. Chapman SA, Spetz J, Seago JA, Kaiser J, Dower C, Herrera C (2009), How have mandated nurse staffing ratios affected hospitals? Perspectives from California hospital leaders J Health Manag 54, 5, 321-333; discussion 334-335.

73. Donaldson N, Shapiro S (2010), Impact of California mandated acute care hospital nurse staffing ratios: A literature synthesis. Policy Polit Nurs Pract 11, 3, 184-201. Erratum. In: Policy Polit Nurs Pract 2010 11(4), 326.

74. McHugh MD, Kelly LA, Sloane DM, Aiken LH (2011), Contradicting fears, California's nurse-to-patient mandate did not reduce the skill level of the nursing workforce in hospitals. Health Aff (Millwood) 30, 7, 1299-1306.

75. McHugh MD, Ma C (2013), Hospital nursing and 30-day readmissions among Medicare patients with heart failure, acute myocardial infarction, and pneumonia. Med Care 51, $1,52-59$.

76. McHugh MD, Rochman MF, Sloane DM, Berg RA, Mancini ME, Nadkarni VM, Merchant RM, Aiken LH, Heart American, American Heart Association's Get with the Guidelines-Resuscitation Investigators (2016), Better nurse staffing and nurse work environments associated with increased survival of in-hospital cardiac arrest patients. Med Care 54, 1, 74-80.

77. Liang YW, Chen WY, Lee JL, Huang LC (2012), Nurse staffing, direct nursing care hours and patient mortality in Taiwan: The longitudinal analysis of hospital nurse staffing and patient outcome study. BMC Health Serv Res 12, 44.

78. Leigh JP, Markis CA, Iosif AM, Romano PS (2015), California's nurse-to-patient ratio law and occupational injury. Int Arch Occup Environ Health 88, 4, 477-484. Erratum. In: Int Arch Occup Environ Health 2015 88, 4, 485-486.

79. Serratt T (2013), California's nurse-to-patient ratios, Part 1: 8 years later, what do we know about nurse-level outcome? J Nurs Adm 43, 9, 475-480.

80. Serratt T (2013), California's nurse-to-patient ratios, part 2: 8 years later, what do we know about hospital level outcomes? J Nurs Adm 43, 10, 549-553.

81. Serratt T (2013), California's nurse-to-patient ratios, part 3 : eight years later, what do we know about patient level outcomes? J Nurs Adm 43, 11, 581-585.

82. Spetz J (2008), Nurse satisfaction and the implementation of minimum nurse staffing regulations. Policy Polit Nurs Pract 9, 1, 15-21.

83. Mark BA, Harless DW, Spetz J, Reiter KL, Pink GH (2013), California's minimum nurse staffing legislation: Results from a natural experiment. Health Serv Res 48, 2 Pt 1, 435-454.
84. Reiter KL, Harless DW, Pink GH, Spetz J, Mark B (2011), The effect of minimum nurse staffing legislation on uncompensated care provided by California hospitals. Med Care Res Rev 68, 3, 332-351.

85. Spetz J, Harless DW, Herrera CN, Mark BA (2013), Using minimum nurse staffing regulations to measure the relationship between nursing and hospital quality of care. Med Care Res Rev 70, 4, 380-399.

86. Tellez M (2012), Work satisfaction among California registered nurses: A longitudinal comparative analysis. Nurs Econ 30, 2, 73-81.

87. Tellez M, Seago JA (2013), California nurse staffing law and RN workforce changes. Nurs Econ 31, 1, 18-26.

88. Tellez MS, Neronde P, Wong S (2013), The great recession of 2007 and California nurses: A descriptive analysis. Policy Polit Nurs Pract 14, 2, 57-68.

89. Staggs VS, Olds DM, Cramer E, Shorr RI (2017), Nursing skill mix, nurse staffing level, and physical restraint use in US hospitals: A Longitudinal Study. J Gen Intern Med 32, $1,35-41$.

90. Field MJ, Lohr KN (1990), Clinical practice guidelines: Directions of a new program, National Academy Press, Washington, DC.

91. Woolf SH, Grol R, Hutchinson A, Eccles M, Grimshaw J (1999), Clinical guidelines: Potential benefits, limitations, and harms of clinical guidelines. BMJ 318, 527-530.

92. Sackett DL, Straus ES, Richardson WS, Rosenberg W, Haynes BR (2000), Evidence-based Medicine, How to practice and teach EBM, Churchill Livingstone, London ISBN-10:0443062404.

93. Scalzitti DA (2001), Evidence-based guidelines: Application to clinical practice. Phys Ther 81, 10, 1622-1628.

94. Kai Biermann K (2018), Keine Zeit für Menschlichkeit, February, 27, 2018, https://www.zeit.de/arbeit/2018-02/ pflege-krankenhaus-arbeit-stress-mangel

95. Jorch G, Kluge S, König F, Markewitz A, Notz K, Parvu V, Quintel M, Schneider D, Sybrecht GW, Waydhas C (2010), Empfehlungen zur Struktur und Ausstattung von Intensivstationen, pp. 1-40. https://www.divi.de/empfehlungen/ publikationen/intensivmedizin/399-empfehlungen-zurstruktur-von-intensivstationen-langversion/file

96. Bundesanzeiger (2018), Verordnung zur Festlegung von Pflegepersonaluntergrenzen in pflegesensitiven Bereichen in Krankenhäusern (Pflegepersonaluntergrenzen-Verordnung PpUGV) vom 05. Oktober 2018. Bundesgesetzblatt I, 34, 1632-1644, https://www.bgbl.de/xaver/bgbl/start.xav? startbk $=$ Bundesanzeiger $\quad$ BGBl\&jumpTo $=$ bgbl118s1632. pdf \# bgbl \%2F\%2 $\overline{\mathrm{F}}^{*} \% 5 \mathrm{~B} \% 40 \mathrm{attr}$ id $\% 3 \mathrm{D} \% 27 \mathrm{bg}-$ bl118s $\bar{s} \overline{6} 32 . p \overline{d f} \overline{\%} 27 \% 5 \mathrm{D} \quad 15504843413 \overline{8} 8$

97. Woratschka R (2018), Mehr als 20 Milliarden an Reserven Krankenkassen schwimmen im Geld, Der Tagesspiegel, https://www.tagesspiegel.de/politik/mehr-als-20-milliarden-an-reserven-krankenkassen-schwimmen-im-geld/ 22992592.html (access January 19, 2019).

98. Ärzteschaft (2016), KBV: Bis 2030 fehlen mehr als 6.000 Ärzte, https://www.aerzteblatt.de/nachrichten/70770/KBVBis-2030-fehlen-mehr-als-6-000-Aerzte (access October 5, 2016).

99. Rothgang H, Klie T, Müller R, Unger R (2012), Themenreport „Pflege 2030" Was ist zu erwarten - was zu tun? Bertelsmann Stiftung, pp. 1-110. https://www.bertelsmannstiftung.de/fileadmin/files/BSt/Publikationen/GrauePublikationen/GP Themenreport Pflege 2030.pdf. 
100. Bogai D, Carstensen J, Seibert H, Wiethölter D, Hell S, Ludewig O (2015), Viel Varianz, Was man in den Pflegeberufen in Deutschland verdient, Institut für Arbeitsmarkt- und Berufsforschung (IAB), Die Forschungseinrichtung der Bundesagentur für Arbeit, Berlin, pp. 1-37.

Cite this article as: Brücher B.L.D.M \& Deufert D 2019. German nursing shortage in hospitals - Homemade by Profititis? 4open, 2,3 . 